\title{
The occurrence of pine needle rust (Coleosporium tussilaginis) on mountain pine (Pinus mugo) in selected regions of Karkonosze National Park
}

\section{Występowanie rdzy pęcherzykowatej sosny (Coleosporium tussilaginis) na kosodrzewinie (Pinus mugo) w wybranych rejonach Karkonoskiego Parku Narodowego}

\author{
Wojciech Pusz*, Włodzimierz Kita
}

\begin{abstract}
Summary
The evaluation of healthiness of infected mountain pine's needles was conducted for two years (2013-2014) at few experimental places: Kopa, Śląskie Kamienie, Kocioł Smogorni, Sokolnik, Łabski Szczyt, Szrenica, Kocioł Małego Stawu and Kocioł Wielkiego Stawu. Needles with symptoms of pine needle rust were found in subalpine zone of Karkonosze Mts. In both years of study disease symptoms were recorded at a level of $5-10 \%$ of evaluated plants growing at Kopa, Łabski Szczyt, Szrenica, Kocioł Małego Stawu and Kocioł Wielkiego Stawu. The most infected needles, up to $10 \%$ occurred in the region of Kocioł Małego Stawu. On the other hand the highest value of disease index was recorded on Kopa and in Kocioł Małego Stawu.
\end{abstract}

Key words: pine needle rust; diseases of mountain pine; Karkonosze Mts.

\section{Streszczenie}

W latach 2013-2014 przeprowadzono badania zdrowotności igieł kosodrzewiny w kilku lokalizacjach na terenie Karkonoskiego Parku Narodowego: Kopa, Śląskie Kamienie, Kocioł Smogorni, Sokolnik, Łabski Szczyt, Szrenica, Kocioł Małego Stawu i Kocioł Wielkiego Stawu. Podczas obserwacji stwierdzono występowanie rdzy pęcherzykowatej igieł. W obydwu latach badań objawy stwierdzano na 5-10\% roślin na stanowiskach zlokalizowanych w rejonie Kopy, Łabskiego Szczytu, Szrenicy oraz w Kotłach: Małego i Wielkiego Stawu. Najwięcej porażonych igieł obserwowano w Kotle Małego Stawu. Najwyższą wartość indeksu chorobowego stwierdzono na Kopie oraz w Kotle Małego Stawu.

Słowa kluczowe: rdza pęcherzykowata sosny; choroby kosodrzewiny; Karkonosze

Uniwersytet Przyrodniczy we Wrocławiu

Katedra Ochrony Roślin

pl. Grunwaldzki 24A, 50-363 Wrocław

*corresponding author: wojciech.pusz@up.wroc.pl 


\section{Wstęp / Introduction}

Rdza sosny [Coleosporium tussilaginis (Pers.) Lév.] jest jedną z chorób często spotykanych na igłach kosodrzewiny, rosnącej na terenach górskich (Karadżič i Miljašewič 2003, 2009; Pusz i wsp. 2013, 2015). Sprawcą tej choroby jest podstawczak - rdzawikowiec pełnocyklowy. Na igłach występuje stadium 0 , I patogena, natomiast stadium III i IV na drugim żywicielu tzn. Tussilago farfara L., Petasites officinalis L., Sonchus arvensis L. czy też Melampyrum pratense L. (Hansen i Lewis 2005; Helpher 2013).

Kosodrzewina (Pinus mugo Turra) jest w Karkonoszach oraz innych masywach górskich środkowej Europy najistotniejszym komponentem flory piętra subalpejskiego (Lokvenc 2001). Dzięki swoim właściwościom pełni ważne funkcje ekologiczne w środowisku wysokogórskim. Jej silnie rozwinięty system korzeniowy zabezpiecza stoki przed erozją, stabilizuje piargi i skalne osuwiska. Kosodrzewina wpływa także na utrzymanie korzystnych warunków termicznych gleby i ogranicza skutki wywołane wietrzeniem mrozowym. Odgrywa też istotną rolę w retencjonowaniu wody pochodzącej $\mathrm{z}$ opadów, a utrwalając pokrywę śnieżną ogranicza powstawanie lawin. Jako gatunek pionierski zasiedla tereny zniszczone przez osuwiska, lawiny oraz działalność człowieka (Mróz i Perzanowska 2004; Pusz i wsp. 2015).

O występowaniu rdzy na igłach kosodrzewiny w naszym kraju praktycznie się nie wspomina, a jeżeli już to pierwsze wzmianki o obecności $C$. tussilaginis na igłach kosodrzewiny rosnącej w Karkonoszach pochodzą z początku 20. wieku (Schroeter 1908). W późniejszym okresie dopiero Lutyk (1978) opisuje w swojej pracy ten gatunek grzyba jako występujący pospolicie na igłach kosodrzewiny w Tatrach.

Celem przeprowadzonych badań było określenie stopnia nasilenia występowania objawów rdzy pęcherzykowatej sosny na igłach kosodrzewiny w Karkonoszach.

\section{Materiały i metody / Materials and methods}

Obserwacje terenowe prowadzono w latach 2013-2014 na wybranych stanowiskach badawczych zlokalizowanych na obszarze Karkonoskiego Parku Narodowego (Kopa, Śląskie Kamienie, Kocioł Smogorni, Sokolnik, Łabski Szczyt, Szrenica, Kocioł Małego Stawu, Kocioł Wielkiego Stawu). W celu oceny nasilenia symptomów rdzy pęcherzykowatej igieł sosny, na każdym stanowisku wybrano 4 obiekty badawcze, na których oceniano występowanie objawów wszystkich chorób w ujęciu procentowym na 10 losowo wybranych pędach, na wysokości około 1,5 metra, określając porażenie na 100 igłach. Nasilenie porażenia igieł oceniano na podstawie opracowanej skali porażenia:

1 - igły na ocenianych pędach zdrowe, bez objawów chorobowych,

2 - pojedyncze plamy (zmiany chorobowe) na igłach, na ocenianych pędach, obejmujące do $5 \%$ powierzchni igły,

3 - plamy (zmiany chorobowe) na igłach, na ocenianych pędach, obejmujące 6-30\% powierzchni igły,
4 - plamy (zmiany chorobowe) na igłach, na ocenianych pędach, obejmujące $31-70 \%$ powierzchni igły,

5 - plamy (zmiany chorobowe) na igłach, na ocenianych pędach, obejmujące powyżej $70 \%$ powierzchni igły lub igły zamierające,

6 - igły zamarłe, przy lekkim poruszeniu pędu odpadają. Opierając się na uzyskanych wynikach obliczano wskaźnik porażenia igieł posługując się wzorem:

$$
\mathrm{Wp}=\sum(\mathrm{P} \times \mathrm{W}) \times 100 / \mathrm{n}
$$

$\sum(\mathrm{P} \times \mathrm{W})-$ suma iloczynów liczby igieł porażonych w określonym stopniu - „P”, przez odpowiadającą im wartość stopnia porażenia - „W”;

$\mathrm{n}$ - liczba wszystkich ocenianych roślin.

Uzyskane wyniki opracowano statystycznie testem t-Studenta.

\section{Wyniki i dyskusja / Results and discussion}

W trakcie badań stwierdzono, że igły kosodrzewiny rosnącej w piętrze subalpejskim Karkonoszy były porażone przez rdzę pęcherzykowatą w zakresie od 5 do $10 \%$ w zależności od stanowiska oraz roku obserwacji. Objawy porażenia stwierdzono jedynie na stanowiskach badawczych zlokalizowanych w rejonie Kopy, Łabskiego Szczytu, Szrenicy oraz w Kotłach: Małego i Wielkiego Stawu (tab. 1). Na stanowiskach, gdzie stwierdzono występowanie C. tussilaginis notowano podobny procent porażonych igieł. Najwięcej zainfekowanych igieł obserwowano w Kotle Małego Stawu w drugim roku badań (10\%). Analizując stopień porażenia igieł kosodrzewiny przez tego patogena stwierdzono, że najbardziej porażone igły występowały w rejonie Kopy. W tym przypadku indeks chorobowy osiągnął średnią wartość 3,6 i była to istotna różnica statystyczna. Rdza pęcherzykowata wystąpiła w mniejszym nasileniu w Kotle Małego Stawu $(2,85)$, natomiast najniższą wartość indeksu chorobowego stwierdzono na Łabskim Szczycie $(1,25)$ oraz na Szrenicy $(1,00)$.

Analizując wyniki badań można stwierdzić, że obecnie rdza pęcherzykowata występuje jedynie lokalnie i nie

Tabela 1. Procent igieł $\mathrm{z}$ objawami rdzy pęcherzykowatej na jednym pędzie kosodrzewiny w lipcu

Table 1. The percentage of needles with symptoms of pine needle rust on one shot of mountain pine in July

\begin{tabular}{l|c|c}
\hline \multicolumn{1}{c|}{$\begin{array}{c}\text { Stanowisko } \\
\text { Location }\end{array}$} & \multicolumn{2}{c}{$\begin{array}{c}\text { Rok obserwacji } \\
\text { Year of observation }\end{array}$} \\
\hline Kopa & 2013 & 2014 \\
\hline Śląskie Kamienie & 5 & 5 \\
\hline Kocioł Smogorni & 0 & 0 \\
\hline Sokolnik & 0 & 0 \\
\hline Labski Szczyt & 0 & 0 \\
\hline Szrenica & 5 & 0 \\
\hline Kocioł Małego Stawu & 5 & 5 \\
\hline Kocioł Wielkiego Stawu & 5 & 10 \\
\hline
\end{tabular}


Tabela 2. Indeks porażenia igieł kosodrzewiny przez Coleosporium tussilaginis w Karkonoszach

Table 2. Index of mountain pine needles infestation by Coleosporium tussilaginis on Karkonosze Mts.

\begin{tabular}{l|c|c|c}
\hline \multicolumn{1}{c|}{$\begin{array}{c}\text { Stanowisko } \\
\text { Location }\end{array}$} & 2013 & 2014 & $\begin{array}{c}\text { Średnia } \\
\text { Average value }\end{array}$ \\
\hline Kopa & 3,5 & 3,7 & $3,60 \mathrm{a}$ \\
\hline Labski Szczyt & 1,1 & 0,9 & $1,00 \mathrm{~b}$ \\
\hline Szrenica & 1,2 & 1,3 & $1,25 \mathrm{~b}$ \\
\hline Kocioł Małego Stawu & 2,9 & 2,8 & $2,85 \mathrm{c}$ \\
\hline Kocioł Wielkiego Stawu & 1,7 & 2,1 & $1,90 \mathrm{~d}$ \\
\hline NIR $(0,05)-$ LSD $(0.05)$ & - & - & 0,321 \\
\hline
\end{tabular}

Wartości oznaczone tą samą literą nie różnią się statystycznie

Means followed by the same letter do not differ significantly

stanowi problemu dla populacji kosodrzewiny w Karkonoszach. Taki stan zdrowotny potwierdzają także inni autorzy, którzy podobne obserwacje prowadzili w Serbii (Karadżič i Miljašewič 2003). Występowanie rdzy pęcherzykowatej sosny zależy od wielu czynników, więc nasilenie choroby może się radykalnie zwiększyć w kolejnych latach lub po zmniejszeniu populacji żywicieli pośrednich zaniknąć. Dominik i Grzywacz (1998) wymieniają też $C$. tussilaginis jako patogena występującego na obcych gatunkach drzew iglastych i mogącego w przyszłości stanowić problem dla np.: Pinus banksiana, P. contorta, $P$. griffithii, $P$. resinosa czy też $P$. rigida. Wydaje się więc, że rdza pęcherzykowata występująca na $P$. mugo może stanowić źródło infekcji w uprawie amatorskiej i szkółkarskiej zarówno kosodrzewiny, jak i dla nowych, nietolerancyjnych dla tego patogena odmian sosen obcych gatunków. Dalsze monitorowanie pojawu rdzy na igłach kosodrzewiny jest konieczne, ponieważ $C$. tussilaginis nie jest jedynym gatunkiem rdzy zagrażającej tej roślinie. Mogą się także pojawić na niej Cronartium flaccidum oraz Peridermium pini (Kaitera i Nuorteva 2008). Karkonoska populacja kosodrzewiny powinna być także objęta stałym monitoringiem, gdyż obserwacje autorów wskazują, że w innych rejonach występowania tej rośliny (Tatry, Masyw Babiej Góry) rdza pęcherzykowata sosny jest najczęściej występującą chorobą na igłach kosodrzewiny (50-80\% roślin wykazuje objawy porażenia) i stanowi tam poważne zagrożenie dla jej kondycji (Pusz i wsp. 2015).

\section{Wnioski / Conclusions}

1. Igły kosodrzewiny rosnącej w Karkonoszach są w niewielkim stopniu porażone przez C. tussilaginis; stan zdrowotny należy jednak monitorować.

2. Rdza pęcherzykowata sosny może być dużym zagrożeniem dla kosodrzewiny, dlatego też konieczny wydaje się monitoring liczebności populacji żywiciela pośredniego.

3. W przypadku wzmożonego występowania choroby na terenie Karkonoszy, może ona stanowić źródło infekcji oraz zagrożenie dla sosen na Pogórzu Sudeckim zarówno w Polsce, jak i w Czechach.

Praca finansowana przez Narodowe Centrum Nauki w ramach grantu N304/069940 „Badania zagrożenia kosodrzewiny (Pinus mugo Turra) w Karkonoskim Parku Narodowym przez grzyby porażające igły”.

\section{Literatura / References}

Dominik J., Grzywacz A. 1998. Zagrożenie obcych gatunków drzew iglastych ze strony rodzimej entomofauny oraz mikoflory. Katedra Ochrony Lasu i Ekologii SGGW, Wyd. SGGW, 138 ss.

Hansen E.M., Lewis K.J. 2005. Compendium of Conifer Diseases. APS Press, St. Paul, MN, 101 pp.

Helpher S. 2013. Coleosporium in Europe. Mycotaxon 124: 87-99.

Kaitera J., Nuorteva H. 2008. Inoculations of eight Pinus species with Cronartium and Peridermium stem rusts. Forest Ecology and Management 255: 973-981.

Karadżič D., Miljašewič T. 2003. The most freguent of rusts on trees and shrubs on Serbia. Bulletin of the Faculty of Forestry 88: 77-101.

Karadżič D., Miljašewič T. 2009. The most important parasitic and saprophytic fungi in Austrian pine and Scots pine plantations in Serbia. Bulletin of the Faculty of Forestry 97: 147-170.

Lokvenc T. 2001. History of Giant Mts.' dwarf pine (Pinus mugo Turra ssp. pumilio Franco). Opera Corcontica 38: 21-42.

Lutyk P. 1978. Stan zdrowotny sosny kosówki (Pinus mughus Scop.) na terenie Tatrzańskiego Parku Narodowego. Sylwan 122 (10): $51-57$.

Mróz W., Perzanowska J. 2004. Zarośla kosodrzewiny (Pinetum mugo). s. 54-62. W: „Poradniki ochrony siedlisk i gatunków Natura 2000 - poradnik metodyczny. Tom 3. Murawy, łąki, ziołorośla, wrzosowiska, zarośla” (J. Herbich, red.). Wyd. Ministerstwo Środowiska, Warszawa.

Pusz W., Kita W., Kaczmarek A., Nowosad K., Koukol O. 2013. Choroby igieł kosodrzewiny (Pinus mugo) w piętrze subalpejskim Karkonoszy. Sylwan 157 (10): 761-769.

Pusz W., Zwijacz-Kozica T., Kita W. 2015. Ocena zdrowotności igieł kosodrzewiny (Pinus mugo) w wybranych lokalizacjach Tatrzańskiego Parku Narodowego. Sylwan 159 (5): 411-418.

Schroeter J. 1908. Pilze. In: Cohn's Krypt. - Fl. Schlesiens 3 (2), Die Pilze Schlesiens II. Breslau, 597 pp. 